Матеріали Всеукраїнської науково-практичної конференчії «Актуальні питання діагностики, лікування, раціональної фармакотерапії, диспансеризації та реабілітації в практиці сімейного лікаря» DOI

\title{
ДИНАМІКА МАСИ ТІЛА ЗА УМОВ ДІЄТ З ВИСОКИМ ВМІСТОМ ЖИРІВ В ЕКСПЕРИМЕНТІ
}

\author{
๑В. І. Величко, В. В. Ткачук, О. Й. Ківа
}

\section{Одеський національний медичний університет}

Причини епідемії ожиріння, що виникла за останні десятиліття, до кінця не вивчені, проте варто визнати, що на збільшення маси тіла у першу чергу впливає склад продуктів харчування.

Останнім часом спостерігається збільшення вживання висококалорійної їжі із високим вмістом жирів [1]. Також змінився і спосіб життя, що пов'язано із широким використанням моторизованого транспорту, зміною характеру праці, що не потребує значних фізичних зусиль. Такий малорухливий спосіб життя супроводжується зниженням енергозатрат [2]. Внаслідок таких змін у структурі харчування і у способі життя, захворювання, пов'язані із харчуванням, зокрема ожиріння, цукровий діабет 2 типу, серцево-судинні захворювання тощо стають усе більш важливими причинами інвалідності і передчасної смерті як у країнах, що розвиваються, так і у розвинутих країнах [3]. Саме тому велике значення в запобіганні розвитку ожиріння має корекція раціонів харчування, а медичним працівникам (насамперед сімейним лікарям) у цих заходах належить провідна і координуюча роль.

Мета дослідження. Для розуміння особливостей впливу раціонів харчування з високим вмістом жирів на розвиток ожиріння був проведений експеримент на тваринах.

Матеріали і методи дослідження. Вивчали ступінь впливу високожирових раціонів на при- ріст маси тіла щурів (самці) лінії Вістар. Тривалість експерименту склала 41 добу. Тварини були поділені на 5 рівномірних груп. Перша група - контрольна, щури, які знаходились на стандартному раціоні віварію. Дослідні групи отримували експериментальні (високожирові) раціони, збагачені соняшниковою (2 група), оливковою (3 група), пальмовою (4 група) оліями чи вершковим маслом (5 група).

Результати й обговорення. Результати досліджень показали, що відносно групи контролю абсолютний приріст маси тіла був вищим у групах тварин, які отримували високожирові дієти. Так, приріст маси щурів 2 групи був вище на $20 \%$ $(p<0,05), 3$ групи - на $24 \%(p<0,05), 4$ групи - на $21 \%(p<0,05), 5$ групи - на $9 \%(p>0,05)$, порівняно із групою контролю.

Висновок. 3 отриманих результатів можна зробити висновок, що усі раціони з високим вмістом жирів призводять до збільшення приросту маси тіла, проте меншою мірою це було характерно для раціону, збагаченого вершковим маслом. Серед дієт, збагачених рослинними оліями, менш виражений вплив на приріст маси тіла спостерігали при застосуванні раціону, збагаченого соняшниковою олією. 